\title{
Guidelines for Useful Integration of Patient-Rated Outcome Measures into Clinical Practice
}

\author{
Skye Livermore-Brasher, MPA, AT'; Russell Baker, PhD, DAT, MS, AT'; Alan Nasypany, Ed.D., M.Ed., AT'; \\ and Scott Cheatham, Ph.D., DPT, LPT, ATC2 \\ ${ }^{1}$ The University of Idaho, Moscow, ID; ${ }^{2}$ California State University Dominguez Hills, Carson, CA
}

\section{Key Phrases}

Patient-reported outcomes, patient education, policy and procedure development

\section{Correspondence}

Skye Livermore-Brasher, University of Idaho, 407 Lumpkin St., Fort Benning, GA 301905.

E-mail: skyelivermore123@hotmail.com

\section{Full Citation}

Livermore-Brasher S, Baker R, Nasypany A, Cheatham S. Guidelines to Useful Integration of Patient-Rated Outcome Measures into Clinical Practice. Clin Pract Athl Train.

2018;1 (2):14-30.

https://doi.org/10.31622/2018/0002.4

Submitted: July 24, 2018 Accepted: October 17, 2018

\section{COMMENTARY}

Outcome measures gauge intervention effectiveness in an evidence-based, patientcentered practice. Patient-rated outcomes (PROs) are tools to measure the perceived effectiveness of a clinician's practice, while serving as instruments to improve clinician-patient communication and health-related quality of life (HRQoL).1,2,3 While clinicians may recognize the importance of PRO usage in practice, adoption into practice can be perceived to be burdensome. In one study, only $26 \%$ of the sample of athletic trainers used PRO measures regularly in practice. ${ }^{4}$ The assortment, variation, and abundance of available measures can be defeating to a clinician who is a novice at utilizing PROs. Clinicians may lack knowledge regarding $P R O$ usage and interpretation, and may struggle with developing the habit of using the instruments in practice. Furthermore, they may lack an understanding of how to interpret PROs for their unique patient populations. The purpose of this paper is to introduce and discuss valid PROs that can be used easily across most athletic training patient populations, and to present a model to begin implementing the use of these PROs in practice.

\section{PATIENT-CENTERED CARE}

Outcome measures are an essential part of wholeperson care, "comprehensive care that considers and addresses all aspects of disability, from the impairment of body structures and functions to activity limitations and participation restrictions." 4 Outcome measure collection is a crucial aspect of patient-centered care for several reasons. First, for individual patients, using outcome measures provides means for patient-clinician communication about HRQoL factors beyond primary complaint, such as social and economic well-being. ' Clinicians may become aware of information about symptoms not discussed during the history, symptoms whose severity was downplayed, or symptoms which are difficult to discuss. ${ }^{3}$ Secondly, outcome measure collection can be used to investigate the effectiveness and efficacy of clinical care by individual healthcare practitioners, clinics, programs, or hospitals, and particular treatments and interventions.' Finally, outcome measure collection improves quality, ${ }^{1}$ evaluating and making changes in clinical care, ${ }^{1}$ and determining the effects of translational research into practice. 5

While athletic training clinicians are already adept at gathering clinician-oriented outcome measures such as range of motion and manual muscle testing, researchers and educators urge clinicians to begin collecting PRO measures. ${ }^{4}$ Generic patient-rated outcome measures address a broad range of health concepts, focus on HRQoL, and cover a wide variety of health domains. 6 Patient-rated outcomes can also be specific measures, such as region-specific (ankle, shoulder), disease specific (migraines, asthma), or 
dimension-specific (pain, fear avoidance) instruments. 6 Patient-rated outcomes provide the patient perspective and a valuable indication of the effects of the patient's condition on HRQoL. ${ }^{4}$ Benefits to PRO use include providing information central to patient-oriented evidence that matters (POEM), advancing the athletic training profession, and enabling evidence-based athletic training practice. ${ }^{6}$ Patients' perceptions of improvement or perceived degree of change may exert an important influence on reports of satisfaction of care. ${ }^{7}$ Clinicians may use data generated by PRO measures along with clinicianrated measures such as range of motion and strength tests as part of an overall clinical outcomes management plan to assess their clinical care and improve their athletic training practice. 2,6,8 These benefits support the immediate adoption of PROs into clinical use.

The general population of athletic trainers, however, has thus far failed to adopt PROs in practice. Valier et al. reported that $74 \%(n=311)$ of athletic trainers who completed a survey about PRO use in practice $(n=421)$ indicated they did not use PRO measures. ${ }^{4}$ This finding is similar to trends in other rehabilitation professions. Nicholas et al. reported that $52 \%$ of clinicians failed to record standardized outcome measures at discharge during a 12-month mandatory reporting period. 9 Barriers identified in the implementation and use of PROs include confusing to the patient, time-consuming for the clinician, and lack of clinician knowledge. 9 The large variety and different classifications of PROs is one reason why PRO use is burdensome to clinicians in routine practice. $^{6}$

\section{EVALUATING THE UTILITY OF A PATIENT- RATED OUTCOME MEASURE}

Two elements of a PRO to consider before implementing a specific measure in practice are essential elements and clinical utility. ${ }^{8}$ Essential elements involve psychometric measures of the soundness of the instrument and its development. ${ }^{8}$ Psychometrics and clinimetrics are the methodologies used to develop and evaluate instruments such as PROs (Table 1). ${ }^{10}$ These

Copyright (C) by Indiana State University All rights reserved. ISSN Online 2577-8188 methodologies are evaluated for a PRO for a wide range of conditions, because the instrument may respond differently in varying populations with varying severity. Two important types of validity are content validity, the extent items in the instrument assess the same content, and construct validity, how well the instrument measures a theoretical construct. ${ }^{9}$ Reliability is a measure of consistency under repetition of constant conditions. 11-13 Responsiveness is a measure of how well the instrument measures change over time. ${ }^{12,13}$ Clinical utility involves the acceptability, feasibility, and appropriateness of using the PRO in clinical practice. ${ }^{8}$ The clinician must determine if the instrument is useful, timeand cost-effective, and acceptable to both himself and the patient. ${ }^{8}$ Clinicians use the minimal clinically important difference (MCID) to measure change. The MCID is a threshold value for change that a patient considers worthwhile and meaningful. ${ }^{14}$ For example, the MCID for the numeric pain rating scale (NRS) is generally considered to be 2 points on a scale from 0 (no pain) to 10 (worst imaginable pain). Once a PRO has been selected that meets both the essential elements and the clinical utility, the implementation into practice becomes easier.

\section{GENERIC PATIENT-RATED OUTCOME MEASURES}

When clinicians decide to incorporate PROs into practice, setbacks may arise in difficulty choosing which measures to use. The sheer number of available instruments may leave the clinician feeling overwhelmed before beginning. A good starting place for the novice PRO user is generic measures because they are designed to be appropriate to a wide range of patients. ${ }^{18}$ Generic patient-rated outcome measures are defined as "scales intended to measure a broad range of health status facets."6 Benefits to generic PROs include applicability to a wide range of patients, ability to compare across groups, and the establishment of normative values within practice. ${ }^{6}$ Generic PROs provide the athletic trainer information about both individual patient 
Table 1. Psychometric Measures in Patient-Rated Outcome Scales

\begin{tabular}{|c|c|c|}
\hline $\begin{array}{l}\text { Psychometric } \\
\text { Measure }\end{array}$ & Definition & \\
\hline Validity & $\begin{array}{l}\text { The soundness or correctness of an } \\
\text { instrument in measuring what it is } \\
\text { designed to measure } 8,10,11,15-18 \\
\text { Does it measure what it is } \\
\text { supposed to measure? }\end{array}$ & $\begin{array}{l}\text { Must be established for each target } \\
\text { population } \\
\text { Correlation Coefficient Values: }{ }^{19} \\
\text { - 1.0: Perfectly negative correlation } \\
\text {-0.8: Strongly negative correlation } \\
-0.5: \text { Moderately negative correlation } \\
-0.2 \text { : Weakly negative correlation } \\
\text { 0.0: No association } \\
+0.2 \text { : Weakly positive correlation } \\
+0.5: \text { Moderately positive correlation } \\
+0.8: \text { Strongly positive correlation } \\
+1.0: \text { Perfectly positive correlation }\end{array}$ \\
\hline Content Validity & $\begin{array}{l}\text { The extent to which the items on a } \\
\text { measure assess the same content, } \\
\text { or how well the content material } \\
\text { was sampled } 8,10,18,20,21 \\
\text { Do experts/patients think it } \\
\text { measures what it is intended to } \\
\text { measure? } \\
\text { Has it been tested on a large } \\
\text { enough sample population? }\end{array}$ & $\begin{array}{l}\text { May be evaluated by expert panel and/or } \\
\text { patients } 8,10\end{array}$ \\
\hline Criterion Validity & $\begin{array}{l}\text { The extent to which a statistically } \\
\text { significant relationship exists } \\
\text { between the measure and a } \\
\text { criterion } 15,18 \\
\text { Does it correspond with a "gold } \\
\text { standard" measure? }\end{array}$ & $\begin{array}{l}\text { Gold standards are difficult to find for PROs } \\
\text { because there is wide variation } 8,10 \\
\text { Often evaluated in comparison with other PROs } \\
\text { or clinical data }^{22}\end{array}$ \\
\hline Construct Validity & $\begin{array}{l}\text { The extent to which a measure } \\
\text { evaluates the theoretical construct } \\
\text { or trait } 8,10,17,18,20 \\
\text { If it is intended to measure a } \\
\text { particular construct (e.g. pain, } \\
\text { function), is that what it measures? }\end{array}$ & Must be established for each population ${ }^{8}$ \\
\hline Reliability & $\begin{array}{l}\text { The measure of consistency of } \\
\text { date when measurements are } \\
\text { taken more than once under the } \\
\text { same conditions } 8,15,17,18,20 \\
\text { If nothing has changed in the } \\
\text { patient's condition, is the score the } \\
\text { same from one point to another? }\end{array}$ & $\begin{array}{l}\text { Establishes that changes observed are due to } \\
\text { intervention and not problems with the } \\
\text { instrument }{ }^{18} \\
\text { Reliability Ranges: }{ }^{23} \\
0.00-0.10: \text { Virtually no reliability } \\
0.11-0.40: \text { Slight reliability } \\
0.41-0.60 \text { : Fair reliability } \\
0.61-0.80: \text { Moderate reliability } \\
0.81-1.0: \text { Substantial reliability }\end{array}$ \\
\hline $\begin{array}{l}\text { Test-Retest } \\
\text { Reliability }\end{array}$ & $\begin{array}{l}\text { The reliability of a patient's } \\
\text { response when the instrument is } \\
\text { administered multiple times }{ }^{24} \\
\text { If a patient's health status does } \\
\text { not change, will the answers } \\
\text { remain the same? }\end{array}$ & $\begin{array}{l}\text { Reflects patient's condition rather than } \\
\text { instrument error } 8,18,24\end{array}$ \\
\hline
\end{tabular}


Table 1. Psychometric Measures in Patient-Rated Outcome Scales (Continued)

\begin{tabular}{|c|c|c|}
\hline $\begin{array}{l}\text { Internal } \\
\text { Consistency }\end{array}$ & $\begin{array}{l}\text { The reliability of the items within } \\
\text { the scale } 8,18,24 \\
\text { Do all items in the instrument } \\
\text { measure the same health domain? }\end{array}$ & $\begin{array}{l}\text { Homogeneity of the questions related to a } \\
\text { specific health domain }\end{array}$ \\
\hline Responsiveness & $\begin{array}{l}\text { The instrument's ability to detect } \\
\text { change over time } 7,15,16,20,21,25 \\
\text { Does it measure change? If no } \\
\text { change occurs, does it remain } \\
\text { static? }\end{array}$ & $\begin{array}{l}\text { Instrument must detect changes over time that } \\
\text { matter to patients } 18 \\
\text { Can be measured statistically or clinically }{ }^{8}\end{array}$ \\
\hline $\begin{array}{l}\text { Standard Error of } \\
\text { Measurement } \\
\text { (SEM) }\end{array}$ & $\begin{array}{l}\text { The variation in score due to error } \\
\text { rather than true observed } \\
\text { change } 8,11,14 \\
\text { How much change is due to error? }\end{array}$ & Point values associated with scale ${ }^{8}$ \\
\hline $\begin{array}{l}\text { Minimal } \\
\text { Detectable } \\
\text { Change (MDC) }\end{array}$ & $\begin{array}{l}\text { The smallest change that can be } \\
\text { measured above that which would } \\
\text { occur due to error } 8,11,20,26,27 \\
\text { How much change is due to } \\
\text { genuine change? }\end{array}$ & Point values associated with scale ${ }^{8}$ \\
\hline $\begin{array}{l}\text { Minimal Clinically } \\
\text { Important Change } \\
\text { (MCID) }\end{array}$ & $\begin{array}{l}\text { A threshold value representing } \\
\text { change that is considered } \\
\text { meaningful and worthwhile by the } \\
\text { patient } 8,14,20,24,28,29 \\
\text { What amount of change is } \\
\text { meaningful to the patient? }\end{array}$ & $\begin{array}{l}\text { Point values associated with scale } 8 \\
\text { Important because clinical measures of } \\
\text { improvement are not necessarily meaningful to } \\
\text { patients, or may not correspond to patients' } \\
\text { perception of improvement or deterioration }{ }^{14}\end{array}$ \\
\hline
\end{tabular}

care and overall practice trends. ${ }^{8}$ Disadvantages include information without sufficient detail to assess specific patient condition, lack of relevancy to some conditions, and less sensitivity to change from an intervention than specific scales. ${ }^{6}$ Commonly used generic PROs are the Short-form Health Survey, Sickness Impact Profile, Child Health Questionnaire, and Pediatrics Outcomes Data Collection Instrument. ${ }^{6}$

Several PROs are applicable in the athletic training setting. The numeric pain rating scale (NRS) is commonly collected during history intake in practice, and can be used as a PRO.30 The global rating of change ( $G R o C)$ is another easyto-implement scale that can be adopted into practice. 22,31 Further, two generic scales may be useful in athletic training because they were designed for physically active populations experiencing musculoskeletal injuries: the PatientSpecific Functional Scale (PSFS) ${ }^{32}$ and the Disablement in the Physically Active scale (DPAS). ${ }^{24}$ These generic PRO measures may be

Copyright (C) by Indiana State University

17 used individually or in conjunction to increase the clinician's understanding of the patient's functional status, disablement, and HRQoL.

\section{FOUR GENERIC PATIENT-RATED OUTCOME MEASURES TO CONSIDER IN PRACTICE:}

\section{Numeric Pain Rating Scale (Table 2)}

Pain is one of the primary reasons patients seek medical attention. 15,30 Each patient presents with a different pain experience that is complete and multidimensional, 15 and the clinician cannot compare the meaning of one person's pain to another. ${ }^{33}$ The NRS can be used to compare the intensity of pain from one time point to another. The NRS is an 11-point scale with no pain as its lower anchor (0) and worst pain imaginable as its upper anchor (10).15,17,30,33-43 The numeric values lack word assignment, allowing each patient to assign importance at each level based on life experience and interpretation. ${ }^{33}$ The clinician can establish a time frame when asking the patient to 
rate pain, such as best, worst, current, at onset, on average, during the last 24 hours, on average during the past 2 days, etc. ${ }^{15,30,33}$ A reduction of score by any patient indicates improvement. ${ }^{33}$ In athletic training practice, the NRS may be used to evaluate immediate changes in the patient's pain from before to after intervention as well as over the duration of care for a particular injury or illness.
Global Rating of Change Scale (Table 3, Appendix 122)

Health-related quality of life (HRQoL) may be difficult to measure as a multifaceted construct. The GRoC is a quick and simple scale used to measure self-perceived change in HQoL. ${ }^{31}$ Unlike other outcome measures which are designed to evaluate a specific dimension of health such as

Table 2: Psychometrics for Numeric Pain Rating Scale (NPRS).

\begin{tabular}{|c|c|}
\hline PURPOSE & Measure perceived intensity of pain $15,30,36,37$ \\
\hline GENERAL DESCRIPTION & $\begin{array}{l}11 \text {-point interval scale ranging from no pain to worst } \\
\text { pain imaginable } 15,17,30,36,38\end{array}$ \\
\hline METHOD OF COLLECTION & Verbal 38 \\
\hline $\begin{array}{l}\text { TEST-RETEST RELIABILITY } \\
\text { (Intraclass correlation coefficient } 2,1 \text { ) }\end{array}$ & $\begin{array}{l}\text { Fair reliability: } \\
\quad 0.5944 \\
\text { Moderate reliability: } \\
0.63 \text { for last } 24 \text { hours, } 0.70 \text { for } 2 \text {-day average } 35 \\
0.63, \mathrm{Cl} 95 \%: 0.28-0.8645 \\
0.74^{17} \\
\text { Substantial reliability: } \\
0.92^{25}\end{array}$ \\
\hline $\begin{array}{l}\text { VALIDITY } \\
\text { (Spearman's R) }\end{array}$ & $\begin{array}{l}0.74, \mathrm{p}<0.001: \text { High validity }{ }^{34} \\
\text { (Strong positive correlation) }\end{array}$ \\
\hline SEM & $\begin{array}{l}1.07(90 \% \mathrm{Cl})^{17} \\
0.86(95 \% \mathrm{Cl})^{25} \\
1.5(95 \% \mathrm{Cl}: 1.3-1.6) 24 \text { hours; } 1.3(95 \% \mathrm{Cl}: 1.1-1.4) \\
2 \text { day }^{35} \\
1.7 \text { (unchanged condition), } 1.8 \text { (minimum change in } \\
\text { condition) }{ }^{44} \\
1.453 \text { Back and buttock, } 1.58 \text { Thigh and leg } 46\end{array}$ \\
\hline MDC & $\begin{array}{l}2.5^{17} \\
2.4^{25} \\
3.5(31 \%) 24 \text { hours; } 3.0(27.3 \%) 2 \text { day }^{35} \\
\text { 4.1 } 44 \\
\text { 3.69 Thigh and leg, } 3.39 \text { Back and buttock } 46\end{array}$ \\
\hline \multicolumn{2}{|c|}{ Minimum Clinically Important Difference } \\
\hline Low Back Pain & $\begin{array}{l}4.0^{25} \\
2.0^{41} \\
1.0^{47}\end{array}$ \\
\hline Shoulder Pain & $\begin{array}{l}1.1^{17} \\
2.2^{39}\end{array}$ \\
\hline Patellofemoral Pain & $1.2^{40}$ \\
\hline Acute Pain & $\begin{array}{l}1.3^{37} \\
1.4^{38}\end{array}$ \\
\hline Fibromyalsia Pain & $2.1^{43}$ \\
\hline Cervical Radiculopathy & $2.2^{44}$ \\
\hline $\begin{array}{l}\text { Aver } \\
\text { MCID for }\end{array}$ & $\begin{array}{l}\text { (from these studies) is } 1.5 \\
\text { (based on these studies): } \mathbf{2 . 0}\end{array}$ \\
\hline
\end{tabular}


Table 3: Psychometrics for Global Rating of Change (GROC) Scale

\begin{tabular}{|c|c|}
\hline PURPOSE & $\begin{array}{l}\text { Measure overall health status based on what is important to } \\
\text { the patient } 22,31\end{array}$ \\
\hline GENERAL DESCRIPTION & $\begin{array}{l}\text { Recall-based questionnaire of well-being based on } \\
\text { progress since initial treatment encounter } 22,48 \\
15 \text {-point scale ranging from "a very great deal worse" }(-7) \\
\text { to "a very great deal better" }(+7)^{22,48} \\
\text { *May also use } 11 \text {-point scale }(-5 \text { to }+5)^{22}\end{array}$ \\
\hline ANTICIPATED TEST LENGTH & Seconds \\
\hline NUMBER OF ITEMS & One item $22,31,48$ \\
\hline METHOD OF COLLECTION & Verbal, ${ }^{22}$ paper, $^{22}$ electronic \\
\hline $\begin{array}{l}\text { TEST-RETEST RELIABILITY } \\
\text { (Intraclass correlation coefficient } 2,1 \text { ) }\end{array}$ & $\begin{array}{l}\text { Substantial reliability: } \\
\quad 0.90, \mathrm{Cl} 95 \%: 0.84-0.93 \text { for } 11 \text {-point scale }{ }^{16}\end{array}$ \\
\hline $\begin{array}{l}\text { VALIDITY } \\
\text { (Spearman's correlation) }\end{array}$ & $\begin{array}{l}0.72, \mathrm{p}<.05 \text { for } 15 \text {-point scale } 16 \\
0.87 \text { for } 7 \text {-point scale } 50 \\
\text { (Strong positive correlation) }\end{array}$ \\
\hline SEM & None reported \\
\hline MDC & .45 on 11 -point scale 22 \\
\hline
\end{tabular}

pain or function, the GRoC allows patients to provide a global rating of their overall health status by choosing what is most important to them. ${ }^{22}$ The GRoC consists of a single question requesting the patients to assess their change on a designated scale from a previous time point to the current time point. ${ }^{13,14,48,49}$ Various numeric scales (i.e., 7-, 11-, and 15-point scales) have been used in research. ${ }^{31}$ Based on clinometric properties, there isn't a difference in responsiveness among the different point scales; however, the 11 -point scale may be easiest to use in clinical practice because it aligns with the 11 point NRS and has similar values (e.g. MDC and MCID) to the NRS. ${ }^{22}$ There are indications that recall bias, i.e. inability to recall the initial status after a period, affects the accuracy of the GRoC. $13,14,48,49$ The GRoC can be meaningful in the athletic training setting when used in conjunction with other generic and regional PROs

\section{Patient-Specific Functional Scale (Table 4 ,} Appendix 232)

Stratford et al. ${ }^{32}$ developed the PSFS in 1995 to provide a resolution to the following problems they observed in the implementation of PROs in orthopedic practice. First, clinicians' caseloads were too varied to support the use of any one, two, or multiple questionnaires. ${ }^{33}$ Secondly, traditional health status measures lacked adeptness at providing valid assessment for

Copyright (C) by Indiana State University All rights reserved. ISSN Online 2577-8188 patients functioning at a high level of independence. ${ }^{32}$ Finally, available measures of improvement did not necessarily emphasize the patient's concept of improvement over that of clinician perceived improvement. ${ }^{32}$ The PSFS is a self-reported, patient-specific measure designed to assess functional change primarily for patients suffering from musculoskeletal disorders. ${ }^{20}$

The format of the PSFS is simple and easy to administer. Patients identify 3-5 important activities that they are unable to perform or with which they are having difficulty due to their injury. ${ }^{32}$ Each activity is rated from 0-10 regarding the current level of difficulty, with the lower anchor (0) indicating that the patient is "unable to perform activity" and the upper anchor (10) indicating an ability "to perform activity at pre-injury level." 32 The PSFS is administered before intervention occurs to maximize focus on functional activity instead of impairment. ${ }^{51}$ Postintervention, the PSFS may be re-administered, and the identified activities may be used throughout the treatment duration to assess change. ${ }^{33}$ However, the patient may nominate new activities that arise when completing the PSFS during follow-up visits. ${ }^{32}$ The structure of the PSFS renders it extremely adaptable to the patient's 
Table 4: Psychometrics for Patient Specific Functional Scale (PSFS).

\begin{tabular}{|c|c|}
\hline PURPOSE & $\begin{array}{l}\text { Determine functional activities most important to an individual } \\
\text { patient with associated rating of difficulty } 20,52-55\end{array}$ \\
\hline GENERAL DESCRIPTION & $\begin{array}{l}11 \text {-point interval scale rating patient-specified functional activities } \\
\text { from } 0 \text { (unable to perform activity) to } 10 \text { (can perform fully) }{ }^{32,52-54}\end{array}$ \\
\hline ANTICIPATED TEST LENGTH & $2-6$ minutes ${ }^{51}, 55$ \\
\hline NUMBER OF ITEMS & Patient-dependent (3-5 activities chosen by the patient) $20,32,55$ \\
\hline METHOD OF COLLECTION & Written 32,55 \\
\hline $\begin{array}{l}\text { TEST-RETEST RELIABILITY } \\
\text { (Intraclass correlation coefficient } \\
2,1 \text { ) }\end{array}$ & $\begin{array}{l}\text { Slight reliability: } \\
0.17 \text { (average) } \\
\text { Fair reliability: } \\
0.59, \mathrm{Cl} 95 \%: 0.23-0.8146 \\
\text { Moderate reliability: } \\
0.71, \mathrm{Cl} 95 \%: 0.51-0.84^{53} \\
0.73, \mathrm{Cl}: 0.49-0.86 \text { (Individual Activity 1), } \\
0.75 \mathrm{Cl}: 0.56-0.87 \text { (Individual Activity } 2)^{56} \\
\text { Substantial reliability: } \\
0.82, \mathrm{Cl} 95 \%: 0.54-0.9345 \\
0.84, \mathrm{Cl} 95 \%: 0.78-0.88^{51} \\
0.86, \mathrm{Cl}: 0.74-0.93 \text { (Individual Activity } 3)^{56} \\
0.87, \mathrm{Cl} 95 \%: 0.72-0.9457 \\
0.91, \mathrm{p}<0.0525 \\
0.92, \mathrm{Cl} 95 \%(\text { lower limit):0.78 (average), } \\
0.91, \mathrm{Cl} 95 \%(\text { lower limit):0.77 (Individual } \\
\quad \text { Activities) } \\
0.9732\end{array}$ \\
\hline VALIDITY (Pearson's R) & $\begin{array}{l}0.77, \mathrm{Cl} 95 \%: 0.61-0.89, \mathrm{p}<0.002^{51} \\
\text { (Strong positive correlation) }\end{array}$ \\
\hline SEM & $\begin{array}{l}0.5^{25} \\
0.41^{32} \\
1.5^{45} \\
1.03^{46} \\
1.3, \mathrm{Cl} 90 \% \text { (individual activity);0.62, C190\% (average score) }{ }^{51} \\
0.35^{57}\end{array}$ \\
\hline & $1.4^{25}$ \\
\hline$M D C$ & $\begin{array}{l}3.3, \mathrm{Cl} 90 \% \text { (average) } \\
2.1^{45} \\
3.4^{46} \\
2.5 \text { (individual activity); } 1.5 \text { (average score) }^{51} \\
2.9, \mathrm{Cl} 95 \%: 1.7-4.2^{53} \\
0.9757 \\
2.0 \text { (individual activity) }^{58}\end{array}$ \\
\hline
\end{tabular}
Minimum Clinically Important Difference (all reported on average score)

\begin{tabular}{ll}
\hline Low Back Pain & $2.3^{25}$ \\
\hline Cervical Radiculopathy & $2.2^{44}$ \\
& $2.0($ Sensitivity 0.95, C195\%:0.77-0.92, Specificity 1.0, \\
& $\mathrm{C} 195 \%: 0.82-1.0)^{45}$ \\
\hline Spinal Stenosis & $1.3^{46}$ \\
\hline Upper Extremity & $1.2(\text { Sensitivity } 0.88, \text { Specificity } 0.79)^{53}$ \\
\hline Shoulder Complaint & 1.2957 \\
\hline Musculoskeletal Injuries & $1.3,2.3,2.7$ (small, medium, large change) $^{59}$ \\
\hline
\end{tabular}

Average MCID (for average score based on these studies) is 2.1

MCID for clinical use (based on Stratford's original report): 2.0 average score; 3.0 for single activity score $^{32}, 55$ 
needs and priorities, further enhancing its applicability in athletic training practice. To be effective in improving patient care, PSFS scores from follow-up visits are compared to those on the initial administration of the scale.

Disablement in the Physically Active Scale (Table 5, Appendix 324)

The Disablement in the Physically Active (DPA) scale was developed by athletic training researchers and is "derived from a disablement framework that includes measures of impairment, functional limitations, and disability." 24 The scale is multidimensional, incorporating measures that evaluate impairments, functional limitations, and disability. ${ }^{24}$ The DPA scale has enhanced value because it includes psychosocial measures. ${ }^{24}$ The DPA scale is an excellent tool to begin use of outcome measurement in clinical practice because it was developed specifically for and by athletic trainers. The format of the scale involves 16 questions. ${ }^{24}$ Questions are rated on a scale of 1 5 , where 1 indicates that the patient does not have this problem and 5 indicates that the patient is severely affected by this problem. ${ }^{24}$ Scores for each question are added, then 16 is subtracted; thus the total score can range from 0-64 where 0 indicates no dysfunction and 64 indicates severe dysfunction. ${ }^{24}$

\section{PRACTICAL USE OF PATIENT-RATED OUTCOME MEASURES}

Hankemeier et al.61 investigated the use of PROs in athletic training practice, finding that most respondents were unfamiliar with various PRO measures and rarely implemented them in practice. Their results were consistent with those of Valier et al, ${ }^{4}$ who reported that $26 \%$ of the athletic trainers responding incorporated PRO measures in patient care. Hankemeier et al.61 proposed increased knowledge, behavioral change, organizational support, and professional responsibility to increase the use of PROs in athletic training practice. A central factor in the adoption of PROs in clinical practice is the intention to do so; the willingness and effort clinicians plan to exert. ${ }^{62}$ One method to increase knowledge about PROs is the publication of

Table 5. Psychometrics for Disablement in the Physically Active (DPA) Scale.

PURPOSE Generic measure of health used in the evaluation of physically active individuals with musculoskeletal injuries measuring impairment, functional limitations, disability, and quality of life $24,26,60$

GENERAL DESCRIPTION

6-item instrument with each response based on a 5point Likert scale from 1 (no problem) to 5 (severe). Once scored, 16 points are subtracted from total score. Score ranges from 0 to 64, with higher scores representing lower levels of HRQoL status $24,26,60$

\begin{tabular}{|c|c|}
\hline METHOD OF COLLECTION & Written $24,26,27,60$ \\
\hline $\begin{array}{l}\text { TEST-RETEST RELIABILITY (Intraclass correlation } \\
\text { coefficient } 2,1 \text { ) }\end{array}$ & $\begin{array}{l}\text { Moderate reliability: } \\
0.7926 \\
\text { Substantial reliability: } \\
0.94, \text { C195\%:0.89-0.9724 }\end{array}$ \\
\hline VALIDITY (Pearson correlation) & $\begin{array}{l}-0.75, \mathrm{p}<0.001 \text { (acute injuries) }{ }^{24} \\
-0.71, \mathrm{p}<0.002 \text { (persistent injuries) }{ }^{24} \\
\text { (Strong negative correlation) }\end{array}$ \\
\hline SEM & $4.5^{26}$ \\
\hline MDC & $12.48^{26}$ \\
\hline \multicolumn{2}{|c|}{ Minimum Clinically Important Difference } \\
\hline Acute Injuries & 924 \\
\hline Persistent injuries & $6^{24}$ \\
\hline
\end{tabular}


easyto-use and read guidelines regarding specific PRO measures. These publications may reduce clinicians' burden in researching measures to use. Clinicians may be more likely to adopt the use of PROs in practice if they perceive a professional obligation to do so. ${ }^{62}$ Employer requirements, as well as National Athletic Trainers' Association position statements, may help increase PRO collection in practice. ${ }^{61}$ Step-by-step guidelines to ease the adoption of PROs into use is necessary to support behavior change as well as knowledge.

One practical guideline for adopting PROs into practice is to use measures that most likely reflect the effects of the athletic training intervention. ${ }^{63}$ The NRS, a measurement of pain intensity, is routinely collected during history and can easily be transformed into an outcome measure by asking for NRS scores after intervention and across subsequent patient encounters. The PSFS scale to assess function can be adopted into the history portion of evaluation, then readministered after intervention and subsequent encounters. The clinician can use NRS and PSFS scores together to form a multifaceted understanding of the patient's pain and function. After intervention, the GRoC is administered to gain understanding of the patient's experienced change. Although all three of these measures can be printed to add to the patient's file, they do not require pen and paper and are therefore easily administered during on-field evaluations, as well as in a clinic-based setting. The DPAS does require pen and paper, and can be administered while the clinician is preparing for the evaluation, then administered at regular intervals during the patient's rehabilitation progression. Overall, the administrative burden in using these PROs is low. (See Table 6 for advantages and disadvantages of each PRO listed.)

The following steps may be taken to adopt these PROs into clinical use:
1. When possible, incorporate PROs into electronic health record (EHR) platforms to save time and improve direct care. 2,67 Some scales have not been validated for electronic use and scores may vary between paper and electronic versions, so clinicians who chose to incorporate PROs into electronic format must switch between formats for a given patient.

2. Use patient portals, tablets, or clinician terminals to collect PROs such as the DPAS before a visit or before beginning evaluation,, 67 or have pen and paper versions available at check in. Alternatively, DPAS forms may be kept with evaluation form, SOAP notes, or near regularly used evaluation tools (e.g. goniometers).

3. Use the most actionable, relevant PROs with fewer than 30 questions. 67 Together, the NRS (current, best, worst, average), PSFS (3-5 specific activities), DPAS (16 questions), and GRoC (1 question) include no more than 26 questions, most of which can be collected during the routine history.

4. Incorporate NRS scores (best, worst, average, current) and PSFS scores into standard evaluation and rehabilitation documents (e.g. flow sheets).

5. Make the PROs relevant to the patient by reviewing the patient's responses in real time and asking follow up questions as part of the evaluation. 2,67

6. Create a sheet with MCIDs for all four PROs or print out accompanying tables.

7. Evaluate patient flow through the athletic training clinic for each clinician to identify key personnel involved in and appropriate timing for the administration of PROs. ${ }^{2,3}$ When all staff members are committed to the collection of PROs, they can work together to determine the best point of collection, analysis, and integration into patient encounters. ${ }^{3}$ 


\section{PRACTICE IMPLICATIONS}

The consensus in the literature indicates each of these PRO measures may be used in conjunction with other generic measures as well as specific measures related to the patient's injury. Both the DPAS and the PSFS are developed specifically for the patient population treated by athletic trainers and are therefore most applicable.
As novice PRO users adopt these measures into their practice, individual patient care will likely improve as they become more competent and comfortable with their use. Clinicians may improve their practice using the information gleaned in regular PRO measurement. Once the athletic trainer becomes adept at the use of these generic measures, more specific measures may be integrated as appropriate.

Table 6: Advantages and Disadvantages of Specific Generic PROs.

\begin{tabular}{|c|c|c|}
\hline & ADVANTAGES & DISADVANTAGES \\
\hline NRS & $\begin{array}{l}\text { Commonly used } 15,17,33 \\
\text { Simple to score } 15,34,37 \\
\text { Quick }^{38} \\
\text { Easy to administer and } \\
\text { record } 15,30,34,36-38 \\
\text { Individuals who are older or less } \\
\text { literate, or have sustained trauma or } \\
\text { lack intact motor skills, can easily } \\
\text { complete the scale } 35,36,38\end{array}$ & $\begin{array}{l}\text { Only measures one dimension (intensity) of a } \\
\text { multifaceted, complex, and contextual } \\
\text { symptom } 15,30 \\
\text { Has less ability to detect change than self- } \\
\text { reported functional measures }\end{array}$ \\
\hline GRoC & $\begin{array}{l}\text { Quick }^{22} \\
\text { Applicable to wide ranges of patient } \\
\text { populations } \\
\text { Easy to understand }^{22} \\
\text { Strong clinical relevance } \\
\text { Adaptable }^{22}, 31 \\
\text { Measures deterioration as well as } \\
\text { improvement }^{22}\end{array}$ & $\begin{array}{l}\text { Relies on patient's estimates of previous health } \\
\text { status }^{22,31,48} \\
\text { Patients may demonstrate recall bias (basing } \\
\text { previous health status on current status) } 22,31,48 \\
\text { Scores may fluctuate with repeated measure } \\
\text { Only correlated to functional measures up to } 3 \\
\text { weeks } \\
\text { (8 }\end{array}$ \\
\hline PSFS & $\begin{array}{l}\text { Patient specific } 20,32,51,55,64 \\
\text { Fast and Efficient } 20,51,55 \\
\text { Easy to use } 20,32,65 \\
\text { Able to assess important change over } \\
\text { time } \\
\text { Formalizes questions asked during } \\
\text { routine evaluation } \\
\text { Aids clinicians in planning treatments } \\
\text { and evaluating progress } 51,55,64 \\
\text { Applicable to a variety of clinical } \\
\text { presentations and demographic } \\
\text { populations }\end{array}$ & $\begin{array}{l}\text { Difficult to compare between patients } 20,53,54,58 \\
\text { Little range available on the scale for patient } \\
\text { to describe decreased ability when condition } \\
\text { deteriorates } 51\end{array}$ \\
\hline DPAS & $\begin{array}{l}\text { Specifically designed for use among } \\
\text { the physically active } 24,27,26,60 \\
\text { Includes } 4 \text { important dimensions of } \\
\text { HRQoL (impairment, functional } \\
\text { limitations, disability, quality of life) }{ }^{24}\end{array}$ & $\begin{array}{l}\text { Scale is new (developed in } 2010)^{24} \\
\text { Lacks clinimetric support } 24,26,27,60\end{array}$ \\
\hline
\end{tabular}




\section{REFERENCES}

1. Deyo RA. Using outcomes to improve quality of research and quality of care. J Am Board Fam Pract. 1998;11(6):465-473. https://https://doi.org/.org/10.3122/iabfm .11 .6 .465

2. Slover JD, Karia RJ, Haver C, Gelber Z, Band PA, Graham J. Feasibility of integrating standardized patient-reported outcomes in orthopedic care. Am J Manag Care. 2015;21(8):e494-500.

3. Rotenstein LS, Agarwal A, O'Neil K, et al. Implementing patient-reported outcome surveys as part of routine care: Lessons from an academic radiation oncology department. J Am Med Inform Assoc. 2017;24(5):964968.

https://https://doi.org/.org/10.1093/iamia Locx009

4. Valier ARS, Jennings AL, Parsons JT, Vela LI. Benefits of and barriers to using patient-rated outcome measures in athletic training. $J$ Athl Train. 2014;49(5):674-683. https://https://doi.org/.org/10.4085/1001 91

5. Koshy E, Koshy V, Waterman H. Action Research in Healthcare. Thousand Oaks, CA: Sage Publications Ltd; 2011.

6. McLeod TCV, Snyder AR, Parsons JT, Bay RC, Michener LA, Savers EL. Using disablement models and clinical outcomes assessment to enable evidence-based athletic training practice, part II: clinical outcomes assessment. J Athl Train. 2008;43(4):437. https://https://doi.org/.org/10.4085/1062 -6050-43.4.437

7. Beattie PF, Nelson RM, Heintzelman M. The relationship between patient satisfaction with physical therapy care and global rating of change reported by patients receiving worker's compensation. Physiother Theory Pract. $2011 ; 27(4): 310-318$. https://https://doi.org/.org/10.3109/0959 3985.2010 .490575

8. Valier AR, Lam KC. Beyond the basics of clinical outcomes assessment: selecting

Copyright (C) by Indiana State University All rights reserved. ISSN Online 2577-8188 appropriate patient-rated outcomes instruments for patient care. Athl Train Educ J. 2015;10(1):91-100.

https://https://doi.org/.org/10.4085/1001 91

9. Nicholas P, Hefford C, Tumilty S. The use of the Patient-Specific Functional Scale to measure rehabilitative progress in a physiotherapy setting. I Man Manip Ther. 2012;20(3): 147-152.

https://https://doi.org/.org/10.1179/2042 $618612 Y .0000000006$

10. Dekker J, Dallmeijer AJ, Lankhorst GJ, et al. Clinimetrics in rehabilitation medicine: current issues in developing and applying measurement instruments 1. 2005. https://doi.org/10.1080/1650197051003 $\underline{5179}$

11. Arnold, BL, Gansneder BM, Perrin DH. Research Methods in Athletic Training. Philadelphia: F.A. Davis Company; 2005.

12. Rubio DM, Berg-Weger M, Tebb SS, Lee ES, Rauch S. Objectifying content validity: Conducting a content validity study in social work research. Soc Work Res. 2003;27(2):94-104.

https://doi.org/.org/10.1093/swr/27.2.94

13. Vincent WJ, Weir JP. Statistics in Kinesiology. Champaign, IL: Human Kinetics; 2012.

14. Copay AG, Subach BR, Glassman SD, Polly DW, Schuler TC. Understanding the minimum clinically important difference: A review of concepts and methods. Spine J. 2007;7(5):541-546.

https://doi.org/:10.1016/i.spinee.2007.01. $\underline{008}$

15. Kahl C, Cleland JA. Visual analogue scale, numeric pain rating scale and the McGill Pain Questionnaire: An overview of psychometric properties. Phys Ther Rev. 2005;10(2):123128

https://doi.org/.org/10.1179/108331905 X55776

16. Costa LOP, Maher CG, Latimer J, et al. Clinimetric testing of three self-report outcome measures for low back pain patients 
in Brazil: Which one is the best? Spine. 2008;33(22):2459-2463. https://doi.org/.org/10.1097/BRS.0b013e $3181849 \mathrm{dbe}$

17. Mintken PE, Glynn P, Cleland JA. Psychometric properties of the shortened disabilities of the Arm, Shoulder, and Hand Questionnaire (QuickDASH) and Numeric Pain Rating Scale in patients with shoulder pain. I Shoulder Elbow Surg. 2009;18(6):920-926. https://doi.org/:10.1016/i.jse.2008.12.015

18. Fitzpatrick R, Davey C, Buxton MJ, Jones DR. Evaluating patient-based outcome measures for use in clinical trials. Health Technol Assess. 1998;2(14): 1-74

19. Zou KH, Tuncali K, Silverman SG. Correlation and simple linear regression. Radiology. 2003;227(3):617-628.

https://doi.org/.org/10.1148/radiol.22730 11499

20. Horn KK, Jennings $S$, Richardson $G$, Van Vliet $D$, Hefford C, Abbott JH. The patient-specific functional scale: Psychometrics, clinimetrics, and application as a clinical outcome measure. I Orthop Sports Phys Ther. $2012 ; 42(1): 30-D 17$.

https://doi.org/:10.2519/iospt.2012.3727

21. Fletcher KE, French CT, Irwin RS, Corapi KM, Norman GR. A prospective global measure, the Punum Ladder, provides more valid assessments of quality of life than a retrospective transition measure. I Clin Epidemiol. 2010;63(10):1123-1131. https://doi.org/.org/10.1016/i.jclinepi.200 9.09.015

22. Kamper SJ, Maher CG, Mackay G. Global rating of change scales: $A$ review of strengths and weaknesses and considerations for design. J Man Manip Ther. 2009;17(3):163170.

\section{https://doi.org/10.1179/imt.2009.17.3.16} $\underline{3}$

23. Shrout PE. Measurement reliability and agreement in psychiatry. Stat Methods Med Res.

1998;7(3):301-317.

Copyright (C) by Indiana State University All rights reserved. ISSN Online 2577-8188 https://doi.org/10.1 177/0962280298007 $\underline{00306}$

24. Vela LI, Denegar CR. The disablement in the physically active scale, part ii: the psychometric properties of an outcomes scale for musculoskeletal injuries. I Athl Train. 2010;45(6):630-641.

https://doi.org/10.4085/1062-6050$\underline{45.6 .630}$

25. Maughan EF, Lewis JS. Outcome measures in chronic low back pain. Eur Spine $J$. 2010;19(9):1484-1494.

https://doi.org/10.1007/s00586-0101353-6

26. Hoch $J M$, Druvenga $B$, Ferguson $B A$, Houston $M N$, Hoch MC. Patient-reported outcomes in male and female collegiate soccer players during an athletic season. I Athl Train. 2015;50(9):930-936.

https://doi.org/10.4085/1062-6050$\underline{50.5 .03}$

27. Houston MN, Van Lunen BL, Hoch MC. Healthrelated quality of life in individuals with chronic ankle instability. J Athl Train. 2014;49(6):758-763. https://doi.org/10.4085/1062-605049.3.54

28. Jaeschke R, Singer J, Guyatt GH. Measurement of health status: Ascertaining the minimal clinically important difference. Control Clin Trials. 1989;10(4):407-415.

29. Cleland JA, Childs JD, Whitman JM. Psychometric properties of the Neck Disability Index and Numeric Pain Rating Scale in patients with mechanical neck pain. Arch Phys Med Rehabil. 2008;89(1):69-74. https://doi.org/10.1016/i.apmr.2007.08.1 $\underline{26}$

30. Williamson A, Hoggart B. Pain: A review of three commonly used pain rating scales. $J$ Clin Nurs. 2005; 14(7):798-804. https://doi.org/:10.1111/i.13652702.2005.01121.x

31. Kamper S. Global rating of change scales. Aust J Physiother. 2009;55(4):289. 
https://doi.org/10.1016/500049514(09)70015-7

32. Stratford P, Gill C, Westaway M, Binkley J. Assessing disability and change on individual patients: A report of a patient specific measure. Physiother Can. 1995;47(4):258263. https://doi.org/10.3138/ptc.47.4.258

33. Farrar JT, Pritchett YL, Robinson M, Prakash A, Chappell A. The clinical importance of changes in the 0 to 10 numeric rating scale for worst, least, and average pain intensity: Analyses of data from clinical trials of duloxetine in pain disorders. I Pain. 2010;11(2):109-118.

https://doi.org/10.1016/i.jpain.2009.06.00 $\underline{7}$

34. Lara-Muñoz $C$, de Leon SP, Feinstein $A R$, Puente A, Wells CK. Comparison of three rating scales for measuring subjective phenomena in clinical research: $i$. Use of experimentally controlled auditory stimuli** Part II of this article will be published in the\# 2, 2004 Issue. Arch Med Res. 2004;35(1):4348.

https://doi.org/10.1016/i.arcmed.2003.07. $\underline{007}$

35. Spadoni GF, Stratford PW, Solomon PE, Wishart LR. The evaluation of change in pain intensity: A comparison of the P4 and singleitem numeric pain rating scales. I Orthop Sports Phys Ther. 2004;34(4):187-193.

36. Bahreini $M$, Jalili $M$, Moradi-Lakeh $M$. A comparison of three self-report pain scales in adults with acute pain. I Emerg Med. 2015;48(1):10-18.

https://doi.org/10.1016/i.jemermed.2014. 07.039

37. Bijur PE, Latimer CT, Gallagher EJ. Validation of a verbally administered numerical rating scale of acute pain for use in the emergency department. Acad Emerg Med. 2003; 10(4):390-392.

https://doi.org/10.1111/i.1553-

2712.2003.tb01355.x

38. Holdgate A, Asha S, Craig J, Thompson J. Comparison of a verbal numeric rating scale

Copyright (C) by Indiana State University All rights reserved. ISSN Online 2577-8188 with the visual analogue scale for the measurement of acute pain. Emerg Med. 2003; 15(5-6):441-446.

https://doi.org/10.1046/i.14422026.2003.00499.x

39. Michener LA, Snyder AR, Leggin BG. Responsiveness of the numeric pain rating scale in patients with shoulder pain and the effect of surgical status. J Sport Rehabil. $2011 ; 20(1): 115$.

https://doi.org/10.1123/isr.20.1.115

40. Piva SR, Gil AB, Moore CG, Fitzgerald GK. Responsiveness of the activities of daily living scale of the knee outcome survey and numeric pain rating scale in patients with patellofemoral pain. $J$ Rehabil Med. 2009;41(3): 1 29-135.

https://doi.org/10.2340/16501977-0295

41. Vela LI, Haladay DE, Denegar C. Clinical assessment of low-back-pain treatment outcomes in athletes. I Sport Rehabil. $2011 ; 20(1): 74-88$.

https://doi.org/10.1123/isr.20.1.74

42. Kendrick DB, Strout TD. The minimum clinically significant difference in patient-assigned numeric scores for pain. Am J Emerg Med. $2005 ; 23(7): 828-832$.

https://doi.org/10.1016/i.ajem.2005.07.00 $\underline{9}$

43. Mease PJ, Spaeth $M$, Clauw DJ, et al. Estimation of minimum clinically important difference for pain in fibromyalgia. Arthritis Care Res. 2011;63(6):821-826. https://doi.org/10.1002/acr.20449

44. Young IA, Cleland JA, Michener LA, Brown C. Reliability, construct validity, and responsiveness of the neck disability index, patient-specific functional scale, and numeric pain rating scale in patients with cervical radiculopathy. Am J Phys Med Rehabil. 2010;89(10):831-839.

https://doi.org/10.1097/PHM.0b013e318 lec98e6

45. Cleland JA, Fritz JM, Whitman JM, Palmer JA. The reliability and construct validity of the Neck Disability Index and patient specific 
functional scale in patients with cervical radiculopathy. Spine. 2006;31(5):598-602. https://doi.org/10.1097/01.brs.00002012 41.90914 .22

46. Cleland JA, Whitman JM, Houser JL, Wainner RS, Childs JD. Psychometric properties of selected tests in patients with lumbar spinal stenosis. Spine J. 2012;12(10):921-931. https://doi.org/10.1016/i.spinee.2012.05.0 $\underline{04}$

47. Lauridsen HH, Hartvigsen J, Manniche C, Korsholm L, Grunnet-Nilsson N. Responsiveness and minimal clinically important difference for pain and disability instruments in low back pain patients. BMC Musculoskelet Disord. 2006;7(1):1. https://doi.org/10.1 186/1471-2474-7-82

48. Garrison C, Cook C. Clinimetrics corner: the global rating of change score (groc) poorly correlates with functional measures and is not temporally stable. I Man Manip Ther. 2012;20(4):178-181.

https://doi.org/10.1179/1066981712Z.00 000000022

49. Schmitt J, Abbott JH. Global ratings of change do not accurately reflect functional change over time in clinical practice. $J$ Orthop Sports Phys Ther. 2015;45(2):106-111. https://doi.org/10.2519/jospt.2015.5247

50. Farrar JT, Young Jr JP, LaMoreaux L, Werth $\mathrm{JL}$, Poole RM. Clinical importance of changes in chronic pain intensity measured on an 11point numerical pain rating scale. Pain. 2001 ;94(2): 149-158.

https://doi.org/10.1016/S03043959(01)00349-9

51. Chatman $A B$, Hyams $S P$, Neel JM, et al. The patient-specific functional scale: measurement properties in patients with knee dysfunction. Phys Ther. 1997;77(8):820-829. https://doi.org/10/1093.pti/77.8.820

52. Stratford PW, Kennedy DM, Wainwright AV. Assessing the patient-specific functional scale's ability to detect early recovery following total knee arthroplasty. Phys Ther.
$2014 ; 94(6): 838-844$.

https://doi.org/10.2522/pti.20130399

53. Hefford C, Abbott JH, Arnold R, Baxter GD. The patient-specific functional scale: validity, reliability, and responsiveness in patients with upper extremity musculoskeletal problems. J Orthop Sports Phys Ther. 201 2;42(2):56-65. https://doi.org/10.2519/iospt.2012.3953

54. Jolles $B M$, Buchbinder $R$, Beaton DE. A study compared nine patient-specific indices for musculoskeletal disorders. J Clin Epidemiol. 2005;58(8):791-801.

https://doi.org/10.1016/i.jclinepi.2005.01. $\underline{012}$

55. Sterling $M$. Patient specific functional scale. Aust J Physiother. 2007;53(1):65-66.

56. Berghmans DD, Lenssen AF, van Rhijn LW, de Bie RA. Patient specific function scale: its reliability and responsiveness in patients undergoing a total knee arthroplasty. J Orthop Sports Phys Ther. 2015;(Early Access): 1-22.

https://doi.org/10.2519/iospt.2015.5825

57. Koehorst ML, van Trijffel $E$, Lindeboom R. Evaluative measurement properties of the patient-specific functional scale for primary shoulder complaints in physical therapy practice. I Orthop Sports Phys Ther. 2014;44(8):595-603. https://doi.org/10.2519/iospt.2014.5133

58. Westaway MD, Stratford PW, Binkley JM. The patient-specific functional scale: Validation of its use in persons with neck dysfunction. I Orthop Sports Phys Ther. 1998;27(5):331-338.

https://doi.org/10.2519/iospt.1998.27.5.3 31

59. Abbott JH, Schmitt JS. The Patient-Specific Functional Scale was valid for group-level change comparisons and between-group discrimination. $J$ Clin Epidemiol. 2014;67(6):681-688. https://doi.org/10.1016/i.jclinepi.2013.11. $\underline{002}$ 
60. Houston MN, Hoch JM, Gabriner ML, Kirby JL, Hoch MC. Clinical and laboratory measures associated with health-related quality of life in individuals with chronic ankle instability. Phys Ther Sport. 2015;16(2):169-175. https://doi.org/10.1016/i.ptsp.2014.10.00 $\underline{6}$

61. Hankemeier DA, Popp JK, Walker SE. Familiarity with and use of clinical prediction rules and patient-rated outcome measures. Athl Train Sports Health Care. 2017. https://doi.org/10.3928/19425864$20170112-02$

62. Ajzen I. The theory of planned behavior. Organ Behav Hum Decis Process. 1991;50(2):179-211. https://doi.org/10.1016/07495978(91)90020-T

63. Ware Jr JE, Brook RH, Davies AR, Lohr KN. Choosing measures of health status for individuals in general populations. Am J Public Health. $1981 ; 71(6): 620-625$. https://doi.org/10.2105/AJPH.71.6.620

64. Novak CB, Anastakis DJ, Beaton DE, Mackinnon SE, Katz J. Validity of the Patient Specific Functional Scale in patients following upper extremity nerve injury. Hand. 2013;8(2):132-138.

https://doi.org/10.1007/s11552-0139506-9

65. Gross DP, Battié MC, Asante AK. The PatientSpecific Functional Scale: Validity in workers' compensation claimants. Arch Phys Med Rehabil. 2008;89(7):1294-1299. https://doi.org/10.1016/i.apmr.2007.11.0 $\underline{40}$

66. Hefford C, Lodge S, Elliot K, Abbott JH. Measuring patient-specific outcomes in musculoskeletal clinical practice: A pilot study. NZ J Physiother. 2008;36(2):42.

67. Wagle N. Capturing the patient voice: implementing patient-reported outcome measures. N Engl J Med Catal. November 2016.

https://catalyst.neim.org/implementingproms-patient-reported-outcome-measures/ 


\section{Appendix 1. Global Rating of Change (GROC)}

Patient Name/Number:

Date:

Global Rating of Change Scale (GROC)

Please rate the overall condition of your shoulder from the time that you began treatment until now (check only one):

A very great deal worse (-7)

A great deal worse (-6)

Quite a bit worse (-5)

Moderately worse (-4)

Somewhat worse $(-3)$

A little bit worse (-2)

A tiny bit worse (-1)
About the same (0)

A very great deal better (7)

A great deal better (6)

Quite a bit better (5)

Moderately better (4)

Somewhat better (3)

A little bit better (2)

A tiny bit better ( 1$)$

Jaeschke R, Singer J, Guyatt GH. Measurement of health status. Ascertaining the minimal clinically important difference. Control Clin Trials 1989: 407-415. 
Appendix 2. Patient-Specific Functional Scale (PSFS)

\section{The Patient-Specific Functional Scale}

This useful questionnaire can be used to quantify activity limitation and measure functional outcome for patients with any orthopaedic condition.

Clinician to read and fill in below: Complete at the end of the history and prior to physical examination.

\section{Initial Assessment:}

I am going to ask you to identify up to three important activities that you are unable to do or are having difficulty with as a result of your_problem. Today, are there any activities that you are unable to do

or having difficulty with because of your_problem? (Clinician: show scale to patient and have the patient rate each activity).

\section{Follow-up Assessments:}

When I assessed you on (state previous assessment date), you told me that you had difficulty with (read all activities from list at a time). Today, do you still have difficulty with: (read and have patient score each item in the list)?

Patient-specific activity scoring scheme (Point to one number):

$\begin{array}{lllllllllll}0 & 1 & 2 & 3 & 4 & 5 & 6 & 7 & 8 & 9 & 10\end{array}$

Unable to perform activity

(Date and Score)

Able to perform activity at the same level as before injury or problem

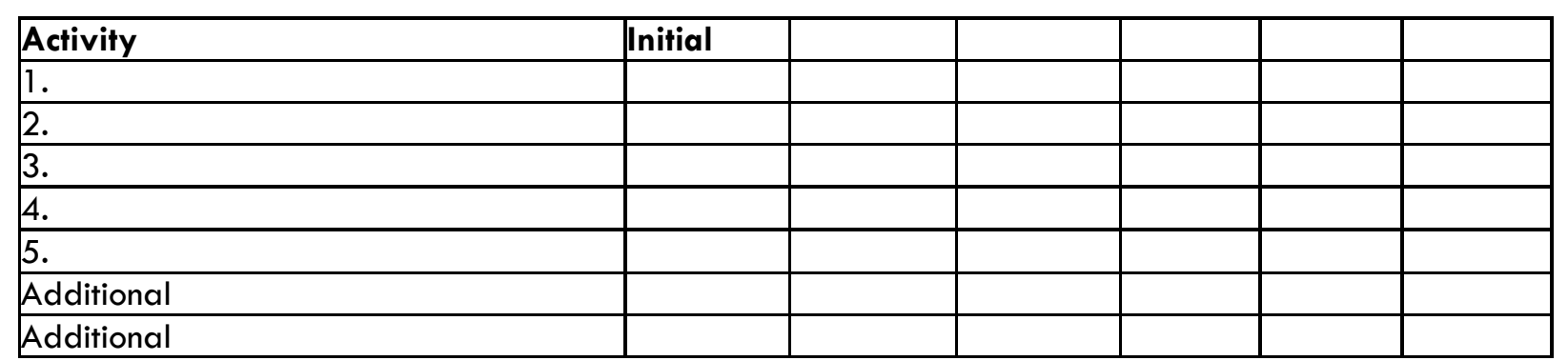

Total score $=$ sum of the activity scores/number of activities Minimum detectable change $(90 \% \mathrm{Cl})$ for average score $=2$ points Minimum detectable change $(90 \% \mathrm{Cl})$ for single activity score $=3$ points

PSFS developed by: Stratford, P., Gill, C., Westaway, M., \& Binkley, J. (1995). Assessing disability and change on individual patients: a report of a patient specific measure. Physiotherapy Canada, 47, 258-263.

(C) P Stratford 1995, reprinted with permission. 


\section{Appendix 3. Disablement in the Physically Active Scale (DPA) Scale}

\section{Disablement in the Physically Active Scale $₫$}

Instructions: Please answer each statement with one response by shading the circle that most closely describes your problem(s) within the past $\mathbf{2 4}$ hours. Each problem has possible descriptors under each. Not all descriptors may apply to you but are given as common examples.

\section{KEY}

1 - no problem

2 - I have the problem(s), but it does not affect me

3 - The problem(s) slightly affects me

4 - The problem(s) moderately affects me

5 - The problem(s) severely affects me

Pain - "Do I have pain?"

Motion - "Do I have impaired motion?"

Ex. decreased range/ease of motion, flexibility, and/or increased stiffness

Muscular Functioning - "Do I have impaired muscle function?"

Ex. decreased strength, power, endurance, and/or increased fatigue

Stability - "Do I have impaired stability?"

Ex. the injured area feels loose, gives out, or gives way

Changing Directions - "Do I have difficulty with changing directions in activity?"

Ex. twisting, turning, starting/stopping, cutting, pivoting

Daily Actions - "Do I have difficulty with daily actions that I would normally do?"

Ex. walking, squatting, getting up, lifting, carrying, bending over, reaching, and going up/down stairs

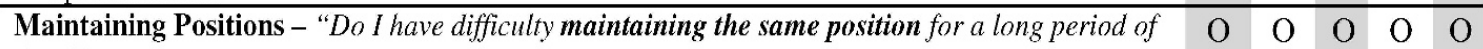
time?"

Ex. standing, sitting, keeping the arm overhead, or sleeping

Skill Performance - "Do I have difficulties with performing skills that are required for physical activity?"

1.) Ex. running, jumping, kicking, throwing, \& catching

2.) Ex. coordination, agility, precision \& balance

Overall Fitness - "Do I have difficulty maintaining my fitness level?"

Ex. conditioning, weight lifting \& cardiovascular endurance

Participation in Activities - "Do I have difficulty with participating in activities?"

1.) Ex. participating in leisure activities, hobbies, and games

2.) Ex. participating in my sport(s) of preference

$\begin{array}{lllll}\mathrm{O} & \mathrm{O} & \mathrm{O} & \mathrm{O} & \mathrm{O}\end{array}$

Well Being - "Do I have difficulties with the following...?"

1.) Increased uncertainty, stress, pressure, and/or anxiety

2.) Altered relationships with team, friends, and/or colleagues

3.) Decreased overall energy

4.) Changes in my mood and/or increased frustration

$\begin{array}{lllll}\mathrm{O} & \mathrm{O} & \mathrm{O} & \mathrm{O} & \mathrm{O}\end{array}$

$\begin{array}{lllll}\mathrm{O} & \mathrm{O} & \mathrm{O} & \mathrm{O} & \mathrm{O}\end{array}$

$\begin{array}{lllll}\mathrm{O} & \mathrm{O} & \mathrm{O} & \mathrm{O} & \mathrm{O}\end{array}$

$\begin{array}{lllll}\mathrm{O} & \mathrm{O} & \mathrm{O} & \mathrm{O} & \mathrm{O}\end{array}$

$\begin{array}{lllll}\mathrm{O} & \mathrm{O} & \mathrm{O} & \mathrm{O} & \mathrm{O}\end{array}$

$\begin{array}{lllll}\mathrm{O} & \mathrm{O} & \mathrm{O} & \mathrm{O} & \mathrm{O}\end{array}$

$\begin{array}{llllll}0 & \mathrm{O} & \mathrm{O} & \mathrm{O} & \mathrm{O}\end{array}$

$\begin{array}{lllll}\mathrm{O} & \mathrm{O} & \mathrm{O} & \mathrm{O} & \mathrm{O}\end{array}$ 